\title{
PENGARUH MOTIVASI DAN KOMUNIKASI TERHADAP KINERJA KARYAWAN PT.PRUDENTIAL LIFE ASSURANCE RANTAUPRAPAT
}

\author{
Elvina \\ Dosen Tetap Sekolah Tinggi Ilmu Ekonomi (STIE) Labuhanbatu
}

\begin{abstract}
ABSTRAK
Hipotesis menggunakan regresi linier berganda, dengan uji $F$, dan secara parsial (uji $t$ ) untuk mengetahui pengaruh variabel bebas terhadap variabel dependen varaibel pada tingkat kepercayaan 95\% atau $\alpha=0,05$. Hasil analisis menunjukkan bahwa pengaruh antara motivasi dan komunikasi terhadap kinerja karyawan PT Prudential Life Assurance Rantauprapat dengan hasil regresi $Y=9,978+0,093 X 1+1,364 X 2$, yang berarti bahwa tanpa motivasi dan komunikasi, kinerja karyawan tetap dengan nilai 9.978. Sedangkan nilai $R^{2}=67,70 \%$ dan variabel lainnya lainnya tidak terpengaruh dalam penelitian ini.
\end{abstract}

Kata kunci: Motivasi, Komunikasi, Karyawan

\section{PENDAHULUAN}

Banyak perusahaan dalam dunia bisnis yang terus tumbuh dan berkembang memegang peranan penting dalam era globalisasi, khususnya yang bergerak dalam sektor jasa dan salah satunya adalah perusahaan asuransi. Perkembangan asuransi dilihat dari maraknya pembukaan cabang-cabang perusahaan asuransi di berbagai daerah. Salah satu persaingan dalam industri asuransi tersebut adalah persaingan industri asuransi jiwa. Kondisi perekonomian melambat yang diwarnai dengan tingginya inflasi dan adanya kenaikan harga bahan bakar minyak (BBM) mempengaruhi daya beli masyarakat terhadap asuransi jiwa.

Munculnya perusahaan-perusahan baru yang sejenis mengharuskan perusahaan tersebut berkompetisi untuk mempertahankan keberadaannya dalam dunia bisnis. Berbagai upaya harus dilakukan yaitu meningkatkan kinerja karyawan. Upaya untuk meningkatkan kinerja karyawan perusahaan asuransi dapat dilakukan dengan meningkatkan produktivitas agen asuransi.

Salah satu asuransi jiwa yang ada di Indonesia adalah PT. Prudential Life Assurance, yang dituntut dapat meningkatkan kinerja karyawan. Kinerja karyawan ini salah satunya harus didukung dengan motivasi yang tinggi dalam bekerja pada diri karyawan. Motivasi ini juga harus dimiliki oleh para agen yang merupakan mitra kerja perusahaan yang berperan sebagai ujung tombak dalam proses pemasaran asuransi. Peningkatan kinerja yang dapat dilakukan oleh agen asuransi adalah menjual sebanyak mungkin produk asuransi kepada calon nasabah. Maka premi yang diperoleh juga akan meningkat. Melalui jumlah premi inilah kinerja agen asuransi dapat dilihat.

PT Prudential Life Assurance sebagai perusahaan yang bergerak dibidang jasa asuransi, dimana dalam menjalankan kegiatan usaha maka perusahaan dalam menawarkan dan menjual polis asuransi kepada masyarakat tidak lepas dari peran serta petugas lapangan asuransi atau agen asuransi yang mereka rekrut. Agen-agen asuransi inilah ujung tombak perusahaan asuransi dalam menarik nasabah, sebab para agen inilah yang berhadapan langsung dengan masyarakat dalam menawarkan dan menjelaskan mengenai asuransi dan produknya. Dalam menghadapi persaingan yang semakin tajam dan mencapai sasaran yang diinginkan maka perusahaan mengharapkan agar para agen asuransi meningkatkan produktivitasnya.

Namun pada kenyataannya masih terdapat kendala dalam mewujudkan harapan perusahaan tersebut, sehingga kinerja karyawan pada perusahaan menjadi tidak maksimal. 
Berdasarkan permasalahan yang terjadi dalam perusahaan bahwa kinerja karyawan agen asuransi masih rendah, hal ini dapat dilihat dari ketidaktercapaian target dalam penjualan produk asuransi. Organisasi yang akan mampu bersaing dan dapat bertahan dalam globalisasi pasar dunia adalah organisasi yang memiliki tingkat kinerja yang tinggi. Sebaliknya organisasi yang memiliki tingkat kinerja rendah secara perlahan ataupun cepat akan kalah dalam persaingan dan akhirnya akan tersingkir. Hasil kerja karyawan ini merupakan suatu proses bekerja dari seseorang dalam menghasilkan suatu barang atau jasa. Proses kerja dari karyawan ini merupakan kinerja dari karyawan.

Agar kinerja agen lebih meningkat, perlu diperhatikan faktor motivasi kerja karena kinerja merupakan hasil kerja dari karyawan yang ditimbulkan dari motivasi dalam upaya perusahaan untuk mencapai tujuan yang telah ditetapkan. Oleh sebab itu, dalam rangka upaya meningkatkan kinerja karyawan maka intervensi terhadap motivasi sangat dianjurkan. Kurangnya kinerja karyawan juga disebabkan karena masih kurangnya motivasi yang diberikan oleh perusahaan seperti pemberian penghargaan terhadap karyawan yang berprestasi, dan kurangnya motivasi dari rekan kerja saat melakukan pekerjaan serta kurangnya perhatian atasan kepada bawahannya saat menyelesaikan tugas yang diberikan.

Komunikasi yang dilakukan oleh segenap lini manajemen perusahaan melalui pertemuan dapat dikatakan berintensitas baik. Namun komunikasi yang dihasilkan dalam pertemuan tidak berjalan dengan efektif yang secara keseluruhan dapat menimbulkan perbedaan pengertian dalam bekerja. Hal inilah yang menuntut setiap karyawan dan pimpinan untuk selalu peka dan saling berkoordinasi agar kelancaran kegiatan perusahaan tetap berlangsung dengan lancar.

Berdasarkan latar belakang diatas maka penulis tertarik untuk melakukan penelitian dengan judul pengaruh motivasi dan komunikasi terhadap kinerja karyawan PT. Prudnetial Life Assurance Rantauprapat.

\section{TINJAUAN PUSTAKA}

\section{Motivasi kerja}

Menurut Ahmad Tohardi (2008) mengemukakan, "motivasi adalah kekuatan (dorongan) dari dalam seseorang untuk melakukan aktivitas sesuai dengan dorongan tersebut". Motivasi atau dorongan yang menjadi pangkal seseorang melakukan sesuatu atau bekerja. Seseorang yang sangat termotivasi, yaitu seseorang yang melakukan subtansial, guna menunjang tujuan-tujuan produksi kesatuan kerjanya, dan organisasi dimana ia bekerja. Seseorang yang tidak termotivasi akan memberikan yang minimum dalam bekerja.

Menurut Douglas Mc Gregor dalam Siagian (2008), teori motivasi kerja, kaitannya dengan pegawai, menyatakan bahwa para manajer menggolongkan para bawahannya pada dua kategori berdasarkan asumsi tertentu. Asumsi pertama ialah bahwa para bawahan tidak menyenangi pekerjaan, pemalas, tidak senang memikul tanggung jawab, dan harus dipaksa agar menghasilkan sesuatu.Sebaliknya dalam organisasi terdapat pula para pegawai yang senang bekerja, kreatif, menyenangi tanggung jawab dan mampu mengendalikan diri. Dari beberapa pendapat dimensi motivasi kerja yang dapat mempengaruhi kinerja aparatur, salah satunya adalah pendapat yang diungkapkan oleh Danim (2006), yang akan dijadikan dimensi penelitian yaitu motivasi kerja terbagi menjadi 2 (dua) komponen yaitu:

1. Komponen Internal yaitu motivasi kerja seseorang pegawai/aparatur yang merupakan hasrat atau dorongan yang positif untuk memenuhi kebutuhan dan harapannya, dengan indikator sebagai berikut: a) Kebutuhan pribadi; b) Keinginan dan harapan; c) Kedewasaan berpikir dan; d) Pengembangan karir. 
2. Komponen Eksternal yaitu motivasi kerja yang muncul dari eksternal aparatur itu sendiri, dengan indikator sebagai berikut: a) Lingkungan kerja; b) Kompensasi; c) Supervisi dan;

d) Penghargaan.

Mangkunegara (2009), mengemukakan bahwa: "Motivasi itu didefinisikan sebagai suatu kecenderungan untuk beraktivitas, mulai dari dorongan dalam diri (drive) dan diakhiri dengan penyesuaian diri”.

\section{Komunikasi}

Menurut Taylor (2007), komunikasi dapat didefinisikan sebagai pemberian, pengiriman atau pertukaran informasi, pendapat atau gagasan secara tertulis, lisan atau dengan alat visual, sehingga materi yang dikomunikasikan dapat dipahami dengan lengkap oleh orang-orang yang berkepentingan. Dengan memilah substansi yang terdapat di dalam definisi ini, maka komunikasi mengandung elemen pengirim informasi, materi informasi, media informasi, dan penerima informasi. Pengirim informasi adalah orang yang memiliki gagasan atau pendapat yang akan dikirimkan/disampaikan; materi informasi adalah gagasan atau ide yang akan dikirimkan; media informasi adalah penyampaian lisan (langsung/pertelepon), tulisan (surat, memo dan pengumuman), alat visual (televisi, proyektor, dan lain-lain); dan penerima informasi adalah orang yang menerima informasi yang dikirimkan.

Istilah komunikasi berasal dari perkataan latin "communicatio" yang berarti "pemberitahuan" atau "pertukaran pikiran". Istilah communicatio tersebut bersumber pada kata "communis" yang berarti "sama". Jadi yang dimaksud sama disini adalah "sama makna".

Jadi di antara orang-orang yang terlibat dalam komunikasi harus terdapat kesamaan makna.Jika tidak terjadi kesamaan makna, maka komunikasi tidak berlangsung. Dengan kata lain apabila seseorang menyampaikan pikirannya atau perasaannya kepada orang lain, maka komunikasi terjadi atau berlangsung jika orang tersebut mengerti apa yang dimaksudkan.Sebaliknya jika tidak paham akan maksudnya, maka orang tersebut tidak menyahut atau tidak memberikan reaksi, berarti komunikasi tidak berjalan.

Pengertian lain tentang komunikasi disampaikan oleh Schiffman dan Kanuk (2009) yang menegaskan, komunikasi adalah pemindahan pesan dari pengirim kepada penerima untuk mengartikan berbagai jenis tanda melalui berbagai jenis saluran. Tidak berbeda dari definisi yang diberikan oleh Taylor dan Stoner (2007), penekanan pengertian atas pesan yang dikomunikasikan merupakan kunci dalam komunikasi. Demikian juga Bowdith dan Buono yang dikutip oleh Kreitner dan Kinicki mengatakan, komunikasi didefinisikan sebagai pertukaran informasi antara seorang pengirim dan seorang penerima, dan penarikan kesimpulan (persepsi) dari orang yang terlibat di dalamnya. Hal ini menjelaskan perbedaan pandangan dan pemahaman atas tiap informasi yang dikomunikasikan dapat saja terjadi. Makin kecil perbedaan pengertian antara pengirim pesan, maka efektif komunikasi yang berlangsung.

\section{Kinerja}

Mangkunegara (2000) menyatakanpengertian kinerja adalah outcome yangdihasilkan secara kualitas dan kuantitas yang dicapai oleh seorang karyawan dalam melaksanakan tugasnya sesuai dengan tanggung jawab yang diberikan kepadanya. Memandang kinerja berdasarkan hasil secara kualitas dan kuantitas.

Mangkuprawira (2012) mengemukakanbahwa kinerja adalah hasil atau tingkat keberhasilan seseorang selama periodetertentu di dalam melaksanakan tugas dibandingkan dengan berbagaI kemungkinan, seperti standar, hasil kerja, target atau sasaran atau kriteria yang telah ditentukan terlebih dahulu dan telah disepakati bersama. Husnan (2002: 126) menetapkan ukuran kinerja berdasarkan empat dimensi dengan interprestasi yaitu (1) kualitas kerja meliputi ketepatan waktu, ketelitian, kemampuan dan ketrampilan karyawan, (2) kuantits kerja meliputi memenuhi standar kerja serta pekerjaan rutin terlaksana dengan cepat, (3) 
tingkatkehandalan meliputi inisiatif, rajin dan kemampuan dalam bekerja, dan (4) sikap meliputi loyalitas dan tanggung jawabkaryawan serta kerja sama dalam tim.

Berbeda dengan Robbins (Wibowo, 2012) mengungkapkan terdapat tiga aspek yang digunakan untuk mengukur kinerja yaitu hasil pekerjaan individu, perilaku (proses) dan sikap kerja.

\section{METODE PENELITIAN}

\section{Populasi dan Sampel}

Populasi adalah gabungan dari seluruh elemen yangberbentuk peristiwa, hal atau orang yang memilikikarateristik yang serupa yang menjadi pusatperhatian seorang peneliti karena itu dipandang sebagai sebuah semesta penelitian (Ferdinand,2006). Populasi yang digunakan dalam penelitian ini adalah seluruh karyawan pada PT. Prudential Life Assurance Rantauprapat sebanyak 30 orang dalam kurun waktu penelitian.

Penentuan sampel dilakukan dengan cara sampel bertujuan atau purposive sampling, dengan metode pemilihan sampel berdasarkan pertimbangan (judgementsampling) tertentu, sehingga diperoleh sampel sebanyak 30 orang.

\section{Metode Analisis Data}

Penelitian ini menggunakan teknik analisisregresi linier berganda untuk pengolahan data dimana teknik ini digunakan untuk mengestimasinilai variabel dependen dengan menggunakan lebihdari satu variabel independen. Untuk mengetahui apakah ada pengaruh yang signifikan dari variabel independen terhadap variabel dependen maka digunakan model regresi linier berganda yang dirumuskan sebagai berikut :

Dimana :

$\mathrm{a}=$ konstanta

$\mathrm{Y}=\mathrm{a}+\mathrm{b} 1 \mathbf{x 1}+\mathbf{b} 2 \times 2+\mathrm{e}$

b1-b2 = koefisien regresi, merupakan besarnya perubahan variabel terikat akibat perubahan tiap-tiap univariabel bebas.

$\mathrm{Y}=$ Kinerja karyawan

$\mathrm{X} 1=$ Motivasi kerja

$\mathrm{X} 2$ = Komunikasi

$\mathrm{e}=$ variabel residual (tingkat eror)

\section{ANALISIS DATA}

Uji Asumsi Klasik

Karena data yang digunakan adalah data sekundermaka untuk menentukan ketepatan model dilakukan pengujian atas beberapa asumsi klasik yang digunakan yaitu : Uji Normalitas, Multikolonieritas, dan Heterokedastisitas. uji normalitas menggunakan kolmogorov-smirnov (K-S) yang nilainya adalah 0,062 sehingga lebih besar dari 0,05 jadi dapat dikatakan jika data terdistribusi secara normal.

Hasil uji multikolinearitas menunjukkan bahwanilai tolerance $=10$ dan $\mathrm{VIF}=10$, sehingga tidak terjadi adanya multikolinearitas. hasil uji heterokedastisitas menunjukkan bahwa c squared hitung lebih kecil dari c squared tabel sehinggadapat disimpulkan bahwa bebas dari heterokedastisitas.

\section{Pengujian hipotesis}

Pengujian hipotesis dalam penelitian ini adalah menggunakan regresi berganda : 


\section{Pengujian hipotesis 1}

Berdasarkan uji-t yang telah dilakukan diperolehbahwa nilai thitung sebesar (+) 60,151 dengan tingkat signifikansi 0,000. Karena tingkat signifikansinya lebih kecil dari 0,05 dan nilai t hitung bertanda positif, maka secara parsial variabel independen motivasi berpengaruh positifsignifikan terhadap variabel dependen kinerja karyawan. Dengan demikian hipotesis yang pertama dapat diterima.

\section{Pengujian Hipotesis 2}

Berdasarkan uji-t yang telah dilakukan diperoleh bahwa nilai t hitung sebesar (+) 1,912 dengan tingkat signifikansi 0,038. Karena tingkat signifikansinya lebih kecil dari 0,05 dan nilai t hitung bernilai positif, maka secara parsial variabel independen komunikasi berpengaruh positif signifikan terhadap variabel dependen kinerja karyawan. Dengan demikian hipotesis yang kedua diterima.

\section{Pengujian Hipotesis 3}

\section{Tabel1.Uji F}

ANOVA ${ }^{a}$

\begin{tabular}{|ll|l|l|l|l|l|}
\hline \multicolumn{2}{|l|}{ Model } & $\begin{array}{l}\text { Sum } \\
\text { Squares }\end{array}$ & Df & Mean Square & F & Sig. \\
\hline 1 & Regression & 302,323 & 2 & 151,162 & 28,249 &, $000^{\mathrm{b}}$ \\
& Residual & 144,477 & 27 & 5,351 & & \\
& Total & 446,800 & 29 & & & \\
\hline
\end{tabular}

a. Dependent Variable: kinerja karyawan

b. Predictors: (Constant), komunikasi, motivasi

Berdasarkan data didapat F-hitungsebesar 28,249 dengan probabilitas F-hitung sebesar $0.000 \mathrm{Hal}$ ini menunjukan bahwa F-hitung lebih besar dari F-tabel yang nilainya 28,249 Karena F-hitung > F-tabel $(28,249>3.35)$ maka Ho ditolak dan Ha diterima. Ini menunjukan bahwa variabel motivasi $\left(\mathrm{X}_{1}\right)$ dan komunikasi $\left(\mathrm{X}_{2}\right)$ secara simultan mempunyai pengaruh yang signifikan terhadap kinerja karyawan.

\section{Uji validitas}

Sebuah instrumen dikatakan valid jika mampu mengukur apa yang diinginkan, dan dapat mengungkap data dari variabel yang diteliti secara tepat. Tinggi rendahnya validitas instrumen menunjukkan sejauh mana data yang terkumpul tidak menyimpang dari gambaran tentang variabel yang dimaksud.

Tabel2. Hasil Uji Validitas

\begin{tabular}{|c|c|c|l|}
\hline $\begin{array}{c}\text { No. Butir } \\
\text { Pertanyaan }\end{array}$ & $\begin{array}{c}\mathbf{r}- \\
\text { hitung }\end{array}$ & $\begin{array}{c}\mathbf{r}- \\
\text { tabel }\end{array}$ & Keterangan \\
\hline 1 & 0,806 & 0,361 & Valid \\
\hline 2 & 0,590 & 0,361 & Valid \\
\hline 3 & 0,715 & 0,361 & Valid \\
\hline 4 & 0,666 & 0,361 & Valid \\
\hline
\end{tabular}




\begin{tabular}{|c|l|l|l|}
\hline 5 & 0,424 & 0,361 & Valid \\
\hline 6 & 0,397 & 0,361 & Valid \\
\hline 7 & 0,481 & 0,361 & Valid \\
\hline 8 & 0,508 & 0,361 & Valid \\
\hline 9 & 0,594 & 0,361 & Valid \\
\hline 10 & 0,411 & 0,361 & Valid \\
\hline 11 & 0,788 & 0,361 & Valid \\
\hline 12 & 0,823 & 0,361 & Valid \\
\hline 13 & 0,782 & 0,361 & Valid \\
\hline 14 & 0,728 & 0,361 & Valid \\
\hline 15 & 0,817 & 0,361 & Valid \\
\hline
\end{tabular}

\section{Uji Reliabilitas}

Uji reliabilitas dimaksudkan untuk mengetahui sejauh mana hasil pengukuran tetap konsisten atau stabil dari waktu ke waktu apabila dilakukan pengukuran dua kali terhadap gejala yang sama dengan menggunakan alat pengukur yang sama. Reliabilitas sebagai konsistensi antar pengukuranpengukuran secara berurutan, dengan demikian uji reliabilitas dilakukan untuk menunjukkan sejauh mana suatu alat pengukur atau kuesioner dapat dipercaya atau diandalkan.

Tabel3ReliabilitasInstrumen

\begin{tabular}{|c|l|l|}
\hline Variabel & $\begin{array}{l}\text { Koefisien } \\
\text { Reliabilitas }\end{array}$ & Keterangan \\
\hline $\mathrm{X}_{1}$ & 0,767 & Reliabel \\
\hline $\mathrm{X}_{2}$ & 0,698 & Reliabel \\
\hline $\mathrm{Y}$ & 0,697 & Reliabel \\
\hline
\end{tabular}

Berdasarkan tabel 3 diatas terlihat bahwa ketiga variabel yaitu motivasi $\left(\mathrm{X}_{1}\right)$, komunikasi $\left(\mathrm{X}_{2}\right)$ dan kinerja karyawan $(\mathrm{Y})$ diatas menunjukkan hasil yang sangat reliabel dengan nilai alpha $>0,60$. Sehingga dari nilai alpha diatas, maka item-item pada variabel diatas dapat digunakan untuk pengukuran selanjutnya.

\section{Koefisien Determinasi $\left(\mathbf{R}^{2}\right)$}

Pengujian koefisien determinasi $\left(\mathrm{R}^{2}\right)$, dilakukan untuk mengukur persentase kemampuan variable bebas dalam menjelaskan perubahan variabel terikat yaitu $(\mathrm{Y})$, dimana 0 $\leq \mathrm{R}^{2} \leq 1$

Tabel 4. Koefisien Determinasi $\left(\mathbf{R}^{2}\right)$ Model Summary ${ }^{b}$

\begin{tabular}{|c|c|c|c|c|}
\hline Model & $\mathrm{R}$ & $\mathrm{R}$ Square & $\begin{array}{c}\text { Adjusted R } \\
\text { Square }\end{array}$ & $\begin{array}{c}\text { Std. Error of } \\
\text { the Estimate }\end{array}$ \\
\hline 1 &, $823^{\mathrm{a}}$ &, 677 &, 653 & 2,313 \\
\hline
\end{tabular}

a. Predictors: (Constant), komunikasi, Motivasi

b. Dependent Variable: Kinreja karyawan 
Berdasarkan hasil SPSS didapat nilai koefisien determinasi sebesar 0,677. Artinya $67,70 \%$ variablemotivasi dan komunikasi mempengaruhi kinerja karyawan dan sisanya sebesar $32,30 \%$ dijelaskan oleh variabel lain.Dengan demikian model regresi linier berganda ini layak dipakai dalam penelitian, karena sebagian besar variabel terikat dijelaskan oleh variabel-variabel bebas yang digunakan dalam model.

\section{DAFTAR PUSTAKA}

Arikunto, Suharsimi. 2012, Prosedur Penelitian (Suatu Pendekatan Praktik), Jakarta, PT Rineka Cipta.

As'ad Mohammad,2007, Psikologi Industri,edisi11, Yogyakarta:Liberty

Anthonius Wisnu Nugroho Edy Mulyantomo (2012), dengan judul pengaruh komunikasi dan motivasi kerja terhadap kinerja karyawan PT.Kresnatel Indonesia Semarang

Danim, Sudarwan.2006. Motivasi, Kepemimpinan dan Efektivitas Kelompok. Cetakan Pertama, Jakarta:PT Rineka Cipta

Davis, Keith dan Newstorm, J.W. 2006. Perilaku dalam Organisasi, Edisi Kesembilan, Diterjemahkan oleh Agus Dharma, Penerbit: Erlangga, Jakarta

Dharma, Surya, 2006. Manajemen Kinerja, Falsafah Teori dan Penerapannya.Pustaka Pelajar, Yogyakarta.

Gibson, James, L. John M, Ivancevich dan James H. Donnelly, Jr., 2006.Organisasi: Perilaku, Struktur, Proses.. Binarupa Aksara, Jakarta.

Gitosudarmo, Indriyo, 2007. PrinsipDasar Manajemen. BPFE,Yogyakarta.

Guritno, Bambang dan Waridin. 2005. Pengeruh Persepsi Karyawan Mengenai Perilaku Kepemimpinan, Kepuasan Kerja dan Motivasi Terhadap Kinerja. JRBI, vol.1 No.1, pp.63-74

Gomez, Faustino Cardoso, 2006. Manajemen Sumber Daya Manusia, ANDIOffset, Yogyakarta.

Ghozali , Imam, 2007. Aplikasi Analisis Multivariat Dengan Program SPSS. Edisi Kelima Badan Penerbit Universitas Dipenogoro, Semarang.

Handoko, T. Hani, 2009. Manajemen Personalia dan Sumber Daya Manusia, BPFE, Yogyakarta.

Hasibuan, Malayu,

S.P. 2013. OrganisasidanMotivasidasarPeningkatanProduktivitas, PT. Bumi Aksara, Jakarta

Hersey, Paul dan Kenneth H. Blancard. 2006. Manajemen Perilaku Organisasi: PendayagunaanSumber Daya Manusia (Penerjemah: Agus Dharma). Jakarta: Gelora Aksara Pratama.

Ishak, Arep \& Hendri Tanjung, 2009. Manajemen Motivasi, PT. Widiasarana Indonesia, Jakarta

Mangkunegara Anwar Prabu, 2009. Manajemen Sumber Daya ManusiaPerusahaan, PT. Remaja Rosdakarya, Bandung. 
Mangkuprawira, Tb. Sjafri, 2009. Manajemen Sumber Daya Manusia Strategik, Ghalia Indonesia, Jakarta

Moekijat, 2009. Dasar-dasar Motivasi, CV. Pionir Jaya, Bandung

Mathis, Robert L, Jackson, John, H, 2006.Manajemen Sumber Daya Manusia, Diterjemahkan oleh Jimmy Sadeli, Bayu Prawira Hie, Penerbit: Salemba Empat, Jakarta

Nawawi, H. 2008. Manajemen Sumber Daya Manusia. Gadjah Mada University Press. Yogyakarta.

Ranupandojo, Heidjrachman dan Suad Husnan, 2007. Manajemen Personalia, BPFE-UGM, Yogyakarta

Rivai, Veithzal, 2008. Manajemen Sumber Daya Manusia untuk Perusahaan,Penerbit: Rajagrafindo Persada, Jakarta

Rahmad Restu Udayanto, I Wayan Bagia, Ni Nyoman Yulianthini (2015) dengan judul pengaruh komunikasi internal dan disiplin kerja terhadap kinerja karyawan pada PT. Coca-cola

Rizon Pranata (2014), dengan judul pengaruh motivasi dan disiplin kerja terhadap kinerja karyawan PT.Adira Dinamika Multi Finance Tbk.Arga Makmur Bengkulu Utara

Santoso, Singgih., 2007. SPSS Statistik Multivariat. PT. Elex Komputindo KelompokGramedia, Jakarta.

Saydam, Gouzal, 2006. Manajemen Sumber Daya Manusia, Djambatan, Jakarta

Sedarmayanti, 2007. Good Governance (Kepemerintahan Yang Baik) Dalam Rangka Otonomi Daerah : Upaya Membangun Organisasi Efektif dan Efisien Melalui Rekstrukturisasi dan Pemberdayaan, Mandar Maju,

Simanjuntak, Payaman J. 2009. Manajemen dan Evaluasi Kinerja. Fakultas EkonomiUniversitas Indonesia, Jakarta. 